\title{
The Relationship between Self-Actualization and Adjustment Among American Catholic Priests
}

Thomas John Murphy

Loyola University Chicago

Follow this and additional works at: https://ecommons.luc.edu/luc_theses

Part of the Psychology Commons

\section{Recommended Citation}

Murphy, Thomas John, "The Relationship between Self-Actualization and Adjustment Among American Catholic Priests" (1972). Master's Theses. 2589.

https://ecommons.luc.edu/luc_theses/2589

This Thesis is brought to you for free and open access by the Theses and Dissertations at Loyola eCommons. It has been accepted for inclusion in Master's Theses by an authorized administrator of Loyola eCommons. For more information, please contact ecommons@luc.edu. (c) (i) $(9)$

This work is licensed under a Creative Commons Attribution-Noncommercial-No Derivative Works 3.0 License. Copyright @ 1972 Thomas John Murphy 
THE RELATIONSHIP BETWEEN SELF-ACTUALIZATION AND ADJUSTMENT AMONG AMERICAN CATHOLIC PRIESTS

BY

THOMAS J. MURPHY

A THESIS SUBMITTED TO THE FACULTY OF THE GRADUATE SCHOOL OF LOYOLA UNIVERSITY IN PARTIAL FULFILLMENT OF THE REQUIREMENTS FOR THE DEGREE OF

MASTER OF ARTS

- JANUARY

1972 


\section{ACKNOWLEDGEMENTS}

The author wishes to express his gratitude to Dr. Thomas Kennedy for his assistance in carrying out this research. He also wishes to express his sincere appreciation to $\mathrm{Dr}$. Ronald Walker and to Dr. Victor Heckler for the assistance which they provided.

The author also wishes to acknowledge Mr. William Flynn and Miss Mary Ellen Murphy who have been most helpful. 


\section{LIFE}

Thomas John Murphy was born in Chicago. Illinois on June 8,1941 . He graduated from Quigley Preparatory Seminary in 1960 and attended St. Mary of the Lake Seminary from 1960 to 1964. He earned a Bachelor of Arts degree in philosophy from St. Mary of the Lake Seminary in 1963.

From 1965 to 1969 he was Assistant to the Dean of the University College division of Loyola University. He received a Master of Education degree from Loyola University in 1966. He began his graduate studies in Clinical Psychology at Loyola University in 1969.

Currently he is doing an internship in psychology at the West Side Veterans' Administration Hospital, Mental Hygiene Clinic. 
TABLE OF CONTENTS

Chapter

Page

I INTRODUCTION $\ldots \ldots \ldots \ldots \ldots \ldots \ldots \ldots \ldots \ldots \ldots \ldots \ldots \ldots \ldots$

The Personal Orientation Inventory.......... 3

The Sentence Completion Method...........15

Psychological Studies of Clergymen............15

III METHODOLOGY AND PROCEDURE..................19

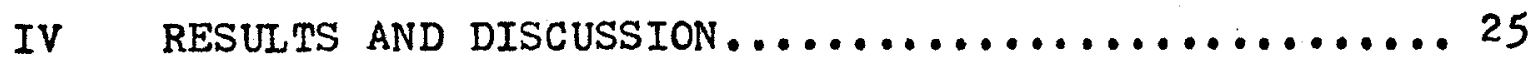

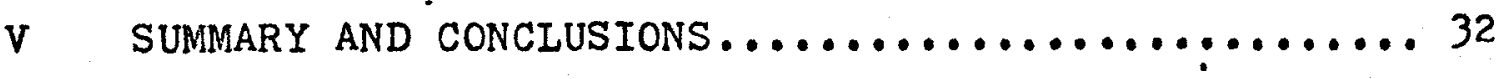




\section{LIST OF TABLES}

Table

1 Number of Priests according to Age..............21

2 Number of Priests according to Years Ordained.......22

3 Correlation of POI Scales against ISCBC Subtests

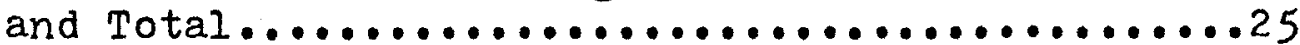

4 Subscale Intercorrelations for the POI...............

5 Intercorrelations for ISCBC Subtests and Total

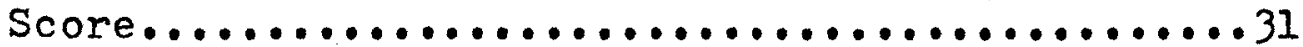




\section{CHAPTER I}

\section{INTRODUCTION}

The purpose of this study is to investigate the relationship between self-actualization and relative adjustment ${ }^{1}$ among American Catholic priests.

There is considerable speculation today about the American priesthood. The traditional roles of the priest are today being questioned, and many priests are seeking new ways within the priesthood to utilize their abilities. A known concern of the American Catholic hierarchy is the great number of priests who have left the priesthood during the last few years and have chosen ways of life which they believe will lead to greater selffulfillment. Thus, an investigation of the relationship between self-actualization and relative adjustment among American CathoIic priests seems worthwhile and timely.

Shostrom (1963) has developed the Personal Orientation Inventory (POI) to measure values which are significant in the attainment of self-actualization. Since there is little known about the relationship of these values to other constructs in personality measurement, it seems worthwhile to examine the relationship between these values and relative adjustment.

In this study relative adjustment will be assessed in terms of feelings and attitudes in the following areas. (1) self-

IThe term "relative adjustment" will be used throughout this study because it is inappropriate to think of adjustment in an absolute sense: no one is perfectly nor completely adjusted. 
perception (2) interpersonal relations (3) psychosexual maturity (4) Church, faith, and religion (5) priesthood and (6) job satisfaction. The Loyola Sentence Completion Blank for Clergymen (ISCBC) (Sheehan, 1971) will be used to measure relative adjustment among American Catholic priests in the above-mentioned areas. 


\section{CHAPTER II}

\section{REVIEW OF THE IITERATURE}

The Personal Orientation Inventory (POI)

The Development of the POI

The Personal Orientation Inventory (POI) was developed by Shostrom (1963) to assess a person's positive mental health or self-actualization. Diagnostic instruments have traditionally focused on measuring psychopathology but have contributed little in assessing a person's potential for therapeutic growth. To meet this need, Shostrom has developed the POI.

This inventory "consists of 150 two-choice comparative value and behavior judgments (Shostrom, 1968, p. 5)." The POI items are first scored for the two basic scales. Inner-Directed Support (127 items) and Time Competence (23 items). The second scoring is for the ten subscales (consisting of from 9-32 items) which measure various aspects of self-actualization. The individual scales of the POI do not have their own exclusive items; rather the scales overlap in their use of test items. For example, item \#1, "I am bound by the principle of fairness," is scored for the following POI scales, Inner-Directed Support, Existentiality, Spontaneity, and Capacity for Intimate Contact.

Shostrom (1968) described the scales of the POI as follows:

$\mathrm{TI} / \mathrm{TC}$ TIME RATIO.

Time Incompetence/Time Competence - measures degree to which one is "present" oriented [23 items].

O/I SUPPORT RATIO

Other/Inner - measures whether reactivity orientation is basically toward others or self [127 items]. 
SAV

SELF-ACTUALIZING VAIUE

Measures affirmation of a primary value of selfactualizing people [26 items].

EX EXISTENTIALITY

Measures ability to situationally or existentially react without rigid adherence to principles

[32 items].

Fr FEELING REACTIVITY

Measures sensitivity of responsiveness to one's own needs and feelings [23 items].

S SPONTANEITY

Measures freedom to react spontaneously or to be oneself [18 items].

Sr SELF REGARD

Measures affirmation of self because of worth or strength [16 items].

Sa SELF ACCEPTANCE

Measures affirmation or acceptance of self in spite of weaknesses or deficiencies [26 items].

NC NATURE OF MAN

Measures degree of the constructive view of the nature of man, masculinity, femininity [16 items].

SY SYNERGY

Measures ability to be synergistic, to transcend dichotomies [9 items].

A ACCEPTANCE OF AGGRESSION

Measures ability to accept one's natural aggressiveness as opposed to defensiveness, denial and repression of aggression [25 items].

C CAPACITY FOR INTIMATE CONTACT

Measures ability to develop contactful intimate relationships with other human beings, unencumbered by expectations and obligations [28 items] (p. 6).

The Personal Orientation Inventory items are based on value judgment problems of patients who were seen in therapy at the Institute of Therapeutic Psychology. The concepts on which the inventory is based stem from well-known sources in the field of psychology--from the "research and theoretical formulations of 
many writers in Humanistic, Existential, or Gestalt Therapy (Shostrom, 1968, p. 25)."

Maslow's concept of self-actualization is reflected in the POI items. He views psychologically healthy individuals as those who have sufficiently satisfied "their basic needs for safety, belongingness, love, respect and self-esteem so that they are motivated primarily by trends to self-actualization... (1962, p. 25)." These individuals more fully use their "talents, capacities, potentials, etc. Such people seem to be fulfilling themselves and to be doing the best that they are capable of doing...(1954, pp. 2̉00-201)."

Maslow does not equate psychological health with adjustment. He wrote, "Adjustment is, very definitely, not necessarily synonymous with psychological health (1968, p. 212)." Maslow (1968) rejects the concept of adjustment as being an "extrapsychic centering point" and an "environment-oriented" concept (pp. 179, 183). He stated, "For a theory of mental health, extra-psychic success is not enough; we must also include intrapsychic health (1968, p. 180)."

The Personal Orientation Inventory items are also based on Reisman, Glazer, and Denney's (1950) concepts of inner-direction and other-direction. They view the inner-directed person as one for whom "the source of direction...is 'inner' in the sense that it is implanted early in life by the elders...(p. 15)." "The inner-directed person has early incorporated a psychic gyroscope which is set going by his parents... He goes through 
life less independent than he seems, obeying this internal

piloting ( $p .24) . "$ on the other hand, the other-directed person depends upon his contemporaries for his source of direction. "While all people want and need to be liked by some of the people some of the time, it is only the modern other-directed types who make this their chief source of direction and chief area of sensitivity ( $p .22) . "$

Shostrom (1968) views the self-actualizing person as more autonomous and less dependent than either the extremely innerdirected person or the extremely other-directed individual. "Whereas he [the self-actualizing person] is other-directed in that he must to a degree be sensitive to people's approval, affection, and good will, the source of his action is essentially inner-directed ( $p .17) . "$

May, Angel, and Ellenberger's (1958) concept of time orientation is also reflected in the Personal orientation Inventory. They emphasize a person's ability to relate the past and the future to the present in a meaningful manner. May, Angel, and Ellenberger stated, "This capacity to transcend the immediate boundaries of time, to see one's experience self-consciously in the light of the distant past and the future, to act and react in these dimensions, to learn from the past of a thousand years ago and to mold the long-time future, is the unique characteristic of human existence (p. 67)."

The Personal Orientation Inventory items are also based on 
Perls' (1951, 1969) concept of time orientation. Whereas Freud emphasized the past and Adler stressed the future, Perls emphasized the here-and-now, the present. Perls, Hefferline, and Goodman (1951) wroter "Delving into the past serves the purpose of finding 'causes'--and thus excuses--for the present situation (p. 38)." They also stated, "People who live futuristically never catch up with the events for which they have prepared and do not reap the fruits of their sowing (p. 39)."

Perls' (1969) stress on the present is indicated in the followings

The time centre of ourselves as conscious human time-space events is the present. There is no other reality than the present. Our desire to retain more of the past or to anticipate the future might completely overgrow this sense of reality. Although we can isolate the present from the past (causes) and from the future (purpose), any giving up of the present as the centre of balance--as the lever of our life--must lead to an unbalanced personality (pp. 91, 92).

In addition to the writings of Maslow (1954, 1962), Reisman, Glazer, and Denney (1950), May, Angel, and Ellenberger (1958), and Perls $(1951,1969)$, Shostrom has also relied on the theoretical formulations of Rogers (1951, 1961), Fromm (1941, 1956), Hormey (1937, 1945, 1950), Ellis (1962), and Buhler (1962) in his attempt to assess self-actualization. Briefly, Shostrom views the self-actualized person as one who uses his talents and capacities more fully, is more autonomous, and is more time competent (lives primarily in the present) than one who is less self-actualized. 
Validity Studies

Shostrom (1964) compared the Personal Orientation Inventory scores of 29 "relatively self-actualized" adults with the scores attained by 34 "relatively non-self-actualized" adults. Persons were nominated as being "relatively self-actualized" and "relatively non-self-actualized" by certified clinical psychologists. Shostrom (1968) reported that the POI "significantly discriminates between clinically judged self-actualized and non-selfactualized groups on 11 of the 12 scales (p. 25)."

Shostrom and Knapp (1966) studied the relationship of a measure of self-actualization (POI) to a measure of pathology (MMPI) and to therapeutic growth. The POI and the MMPI were both administered to two groups of outpatients in therapy, one a beginning group of 37 patients and the other a group "of 39 patients in advanced states of psychotherapeutic progress (p. 194)." Shostrom and Knapp reported that "all of the 12 POI scales differentiated between the criterion groups at the .01 confidence level or higher (p. 196)." The authors also found that the MMPI differentiated between the beginning group and the advanced group of outpatients at the .01 confidence level on four scales (Depression, Psychopathic Deviate, Psychasthenia, and Schizophrenia), and at the .05 level of significance on three scales (Hypochondriasis, Hysteria, and Paranoia). Shostrom and Knapp indicate that their results suggest "that, as therapy progresses, pathology as measured by the MMPI 'decreases' and health, as measured by the POI, 'increases: ( $p$. 201)." 
Zaccaria and Weir (1967) studied 70 adults who participated in an alcoholic treatment program. "Of this group, 38 were male alcoholics, seven were female alcoholics, and 25 were non-alcoholic wives of male alcoholics (p. 152)." The authors compared the POI scores of these subjects (the experimental group) with the scores obtained by normals, self-actualized, and non-self-actualized adults in Shostrom's study (1964). Zaccaria and Weir found that the POI significantly distinguished between the self-actualized group and the experimental group. The POI also significantly differentiated between the normal group and the experimental group on 11 scales. However, the non-selfactualized group was differentiated significantly from the experimental group on only one POI scale (the non-self-actualized group was more "time competent" than the experimental group); no significant differences were reported for the remaining 11 scales.

The Personal Orientation Inventory was used by Fox, Knapp, and Michael (1968) to assess the self-actualization of 185 hospitalized psychiatric patients. The authors reported that "all POI scales significantly differentiated the hospitalized population from normal and self-actualized samples (p. 569)." Fox, Knapp, and Michael also stated, "With one exception differences between the hospitalized and clinically nominated, nonself-actualized samples were in the expected direction for all scales ( $p .567$ )." The authors indicated, "Seven out of the 12 differences obtained were significant at or beyond the .05 level (p. 567)." 
Fisher (1968) investigated the performance of 150 psychopathic felons on the POI. He reported that the means for this sample were "significantly lower than those for the normal Ss (except for $\mathrm{Sr}$ which was higher and SAV, S and $\mathrm{C}$ which did not differ); [and] significantly higher than those for the psychiatric patients...(p. 562)."

Knapp (1965) investigated the relationship between self-actualization as measured by the Personal Orientation Inventory (POI) and neuroticism and extraversion as measured by the Eysenck Personality Inventory (EPI) in a sample of 136 college students. He reported that self-actualization is "positively and significantly related to a lack of neurotic symptoms and tendencies (p. 170)." Knapp also stated that 7 of the 12 POI scales were significantly related to the extraversion dimension of the EPI. He indicated that the "positive relationship to extraversion might suggest that extraverted temperaments in general are more self-actualized (p. 171)." Knapp also reported that among "low neurotics" (those scoring in the lower $27 \%$ on the Neuroticism dimension of the EPI) self-actualization is not related to extraversion-introversion. However, among "high neurotics" (those scoring in the upper $27 \%$ on the Neuroticism dimension) the author indicated that the "extravert is seen to be relatively more self-actualized than the high neurotic introvert (p. 171)."

Grossack, Armstrong, and Iussiev (1966) reported the results of a student research project which focused on personality correlates of self-actualization. Using a sample of 71 college students, the authors found positive correlations between Auton- 
omy and Heterosexuality on the Edwards Personal Preference

Schedule (EPPS) and Self-Actualization, as measured by the support ratio of the POI. Abasement and Order on the EPPS were negatively correlated with Self-Actualization. On the Cattell 16PF Test, the variables bright-intelligent and experimenting-critical correlated positively with self-actualization; the variables tense-excitable and aloof-cold were found to correlate negatively with selfactualization.

Le May and Damm (1969) controlled for sex differences in investigating the relationship between the Personal Orientation Inventory and the Edwards Personal Preference Schedule. For 93 college male freshmen, the authors found that 5 of the 12 POI scales correlated positively and significantly with the Autonomy scale of the EPPS; 7 POI scales correlated negatively with Abasement. For 101 female college freshmen, a positive significant relationship was found between Change and 4 POI scales; a significant negative correlation was found between Order and 4 POI scales. Graff, Bradshaw, Danish, Austin, and Altekruse (1970) investigated the relationship between the POI scales and the effectiveness of dormitory assistants. The POI was administered to 71 male dormitory assistants. Their effectiveness as dormitory assistants was assessed by a semantic differential questionnaire which was completed by 2.963 junior and senior college students. The authors stated that "the results provided support for several of the POI variables in predicting effectiveness of dormitory assistants when using students' ratings as a criterion measure (p. 431)." Graff, Bradshaw, Danish, Austin, and Altekruse indicated, "The 
findings suggested that the Inner Directed, Self-Actualizing Value, Spontaneity, and Acceptance of Aggression were the primary scales of the POI which predicted effectiveness in the diverse roles of dormitory assistants when using student rating (p. 432)."

\section{Summary of Validity studies}

In reviewing the validity studies of the POI, we find that the POI significantly differentiated between persons clinically nominated as self-actualized $(N=29)$ and those nominated as nonself-actualized $(N=34)$ (Shostrom, 1964). A limitation to this study is the small number of self-actualized and non-self-actualized subjects. The POI was also successful in differentiating beginning outpatients in therapy $(N=37)$ from those in the advanced stages of therapy $(\mathrm{N}=39)$ (Shostrom and Knapp, 1966). This study is also somewhat limited by the small number of subjects. The POI significantly differentiated psychiatric patients from normal and self-actualized groups (Fox, Knapp, and Michael, 1968). The inventory was also found to distinguish self-actualized and normal adults fromalcoholics (Zaccaria and weir, 1967). In addition, the POI differentiated psychopathic felons from normal subjects (Fisher, 1968). Fox, Knapp, and Michael, Zaccaria and Weir, and Fisher compared the POI scores of their special groups (psychiatric patients, alcoholics, and psychopathic felons respectively) with those attained by Shostrom's (1964) subjects in his study of self-actualized, normal, and nonself-actualized persons. A limitation to these studies is that neither Shostrom nor the above-mentioned authors specify such 
variables as age, educational level, or socioeconomic status of their subjects. (The one exception is Fisher's (1968) study in which age, IQ, and reading grade level are indicated.) Therefore, no indication is given regarding how similar or dissimilar these groups are to Shostrom's subjects with respect to the above-mentioned variables.

The POI also significantly differentiated those attaining a high score on the Neuroticism scale of the Eysenck Personality Inventory from those scoring low in this dimension (Knapp, 1965). POI scales have been found to correlate positively with Autonomy and negatively with Bbasement and Order on the Edwards Personal Preference Schedule (Grossack, Armstrong, and Lussiev, 1966, Ie May and Damm, 1969). In addition, Graff, Bradshaw, Danish, Austin, and Altekruse (1970) reported that the POI "may have practical value as a tool in the selection of dormitory assistants (p. 432)."

In conclusion, despite the limitations of the above-mentioned studies, they do lend support to the POI as a measure of selfactualization.

Reliability of the POI

Shostrom (1963) reported test-retest reliability coefficlents of .91 and .93 for the Time Competence Ratio and for the Support Ratio (inner-other directedness) of the POI.

Klavetter and Mogar (1967) investigated the reliability of the Personal Orientation Inventory using a sample of 48 undergraduate college students who took the test "on 2 occasions separated by a 1-wk. interval (p. 423)." The authors reported 
test-retest reliability coefficients of .71 and .77 for the major scales of Time Competence and Inner-Direction. Reliability coefficients ranging from .52 to .82 were reported for the POI subscales. Klavetter and Mogar pointed out that Inner-Direction, Time Competence, and Self-Actualizing Value "account for almost all of the tests's variance ( $p .424)$." They stated that "performance on this test would be expressed more accurately and parsimoniously in terms of fewer dimensions ( $p .424) . "$ The authors concluded: "The results also suggest the need for an item analysis as a basis for eliminating superfluous subscales and minimizing the number of items keyed on more than one scale (p. 424)." Ilardi and May (1968) studied the reliability of the POI using a sample of 46 female nursing students at the University of Tennessee College of Nursing. The test was re-administered to the students after approximately 50 weeks. "The range of product-moment correlations for the 12 subscales was .32 to .71 (median $r=.58$ ) with the major scales of Time Competence and Inner-Direction yielding correlations of .55 and .71 , respectively (p. 70)." The authors indicated, "The findings reported on the POI are well within these ranges of somewhat comparable MMPI and EPPS [Edwards Personal Preference Schedule] test-retest reliability studies ( $p .71)$."

Although Klavetter and Mogar (1967) and Ilardi and May (1968) do not report reliability coefficients as high as those reported by Shostrom (1963), the test-retest reliability of the Personal Orientation Inventory is comparable to other widely used person- 
ality measures.

The Sentence Completion Method

In a comprehensive review of the sentence completion method, Goldberg (1965) stated that this technique is useful in assessing adjustment, and that it compares well with other standard instruments. Goldberg (1968) indicated that "it is precisely in the area of assessing adjustment that the supporting evidence for the sentence completion is most impressive ( $p$. 219)." Murstein

(1965) stated that "the sentence completion method is a valid test, generally speaking, and probably the most valid of all the projective techniques reported in the literature (p. 777)." Psychological Studies of Clergymen

Studies Using the POI

Webster (1966) investigated dogmatism, mental health, and psychological health among 191 students in Protestant seminaries in the United States, Australia, and New Zealand. To assess dogmatism, mental health, and psychological health, the author used the Dogmatism Scale (Rokeach, 1960), the MMPI, and the POI respectively. Webster reported a negative relationship between dogmatism and psychological health. He found a positive significant relationship between dogmatism and the Iie scale (I) and the Social Introversion scale (Si) of the MMPI. Negative significant correlations were found between dogmatism and the $K$ (defensiveness), Hysteria ( $\mathrm{Hy}$ ), and Paranoia ( $\mathrm{Pa}$ ) scales of the MIMPI. Webster stated, "It is suggested that closed-mindedness [dogmatism] may act as a defense against problems which might tend to 
produce these pathological reactions ( $p, 212)$ " He added,

"However, if $\mathrm{K}$ be taken as a measure of self-respect, the negative relationship with closed-mindedness is psychologically consistent ( $p$. 212)." The author reported a positive significant relationship between psychological health and the K, Hysteria (Hy), Masculinity-femininity (Mf), Paranoia ( $\mathrm{Pa}$ ), and Hypomania (Ma) scales of the MMPI. Webster suggested "that higher scores within the normal deviations in psychopathology can be correlates of better psychological health (p. 214)."

Webster and Stewart (1969) studied the psychological attitudes and beliefs of ministers in New Zealand. The authors concluded that "there is a very high likelihood that the minister who scores, higher on theologically conservative (ThC) statements will be dogmatic (Dog.), generally conservative (GC), ethnocentric (Eth), low on Iiberal theological orientation (TOI) and non-selfactualizing, especially dependent (I-scale with negative correlation), rigid (Ex), insensitive $(F r)$, rejecting of human nature (Nc) and not good in interpersonal relationships (C) (p. 13)." Webster and stewart reported that the minister who is theologically liberal "is almost the mirror opposit $\ldots \ldots(p .13) . "$

Studies Using the Sentence-Completion Method

Gorman and Kobler (1963) devised a sentence completion method for use with seminarians, the Loyola Seminarian Sentence Completion Test (ISSCT). On this test, a high score is indicative of maladjustment. Sheridan (1968) reported, "Seminarians 
judged in need of counseling, both by three elevated MMPI scales and psychologists' ratings, scored significantly higher on the ISSCT than seminarians judged, by the same criteria, not in need of counseling ( $p .28) . "$

Sheehan (1971) developed the Loyola Sentence Completion Blank for Clergymen (ISCBC). Iike the ISSCT, a high score on the Ioyola Sentence Completion Blank for Clergymen is indicative of maladjustment. This instrument was administered to 115 priests who were enrolled in the 1969 summer session of the Loyola Pastoral Institute. A random sample of 60 of these protocols was selected in order to study the reliability and validity of the test. In order to assess the validity of the instrument, biserial correlations were computed "using the ISCBC scores and (1) an MMPI criterion of adjustment [N=37] (2) psychologists' ratings of adjustment based on in-depth interviews $[N=37]$, and (3) a combination of these two criteria $[N=16]$ (p. 47)." Those whose MMPI profiles had 2 or more clinical scales greater than or equal to 70 made up the group which was poor in adjustment; those who had no clinical scales greater than 65 made up the group which was judged to have good adjustment (the Mf scale was omitted). The psychologists' ratings of adjustment consisted of "their rating of normal or abnormal. the Westley and Epstein Scale of Adjustment rating, and the Grinker et al. Behavior Rating Scale A...(p. 34)." Sheehan reported, "In all three cases [using all three criteria] when using total ISCBC scores," the biserial correlation was signifi- 
cant at the .01 level (p. 47). The author also indicated that the highest correlation was "obtained when using the combined criteria $\left(r_{\text {bis }}=.86\right)(\mathrm{p} .47) . "$ A correlation of .66 (significant at the .01 level) was reported between ISCBC total score and psychologists' ratings of adjustment. In addition, the author reported a correlation of .62 (significant at the .01 level) between ISCBC total score and the MMPI indication of adjustment. Sheehan concluded that "the ISCBC does give a useful indication of adequate versus inadequate adjustment for clergymen (pp. 4748)."

Sheehan also intestigated the inter-scorer reliability of the Loyola Sentence Completion Blank for Clergymen using a sample of 30 protocols. She reported: "Using an empirically-derived scoring manual, two judges agreed significantly on total as well as subtest scores. Pearson $\underline{n}^{\prime}$ s ranging from .84 to .96 (p. 47)."

In summary, the research literature reviewed lends support to the Personal Orientation Inventory as a measure of selfactualization and to the Loyola Sentence Completion Blank for Clergymen as a measure of adjustment. 


\section{CHAPTER III \\ METHODOLOGY AND PROCEDURE}

Subjects

The subjects of this thesis are participants of a larger study entitled The Loyola Psychological Study of the Ministry and Life of the American Priest (Kennedy and Heckler, 1971 ). The latter is a part of a larger project which is sponsored by the American Catholic Bishops Committee on Pastoral Research and Practices.

The goal of the sampling methodology was to select a sample size that would not be overwhelming in terms of time and expense but would accurately reflect the dimension of the estimated population characteristics. After consultation with experts in sampling strategy at the Survey Research Center at the University of Michigan and at the National Opinion Research Center at the University of Chicago, a sampling strategy was devised by Benjamin King. Sampling Director of the National Opinion Research Center (Kenndy and Heckler, p. 54).

A stratified sampling procedure was used in which the "strata" were size categories of dioceses and religious orders. "In order to insure that priests from all size categories would be represented, it was decided that diocess and religious communities would be stratified according to the number of priests contained within them and then selected as first-stage sampling units or clusters (Kennedy and Heckler, 1971, p. 54)." 
The size categories for dioceses were, Small (1-100 priests). Medium (101-200 priests), Large (201-500 priests), Extra Large (501 priests or more). The size categories for religious communities were, Extra Small (1-20 priests). Small (21-50 priests). Medium ( $51-135$ priests), and Large (136 or more priests).

In addition to strata based on size, two strata were formed for groups which were considered to be somewhat special, the Trappists and the United States Foundations. After the subjects were divided into size strata and the two special strata, "the dioceses and religious communities. were arranged in geographical order according to the four major united States census regions and then sampled within each stratum (Kennedy and Heckler, p. 55)."

A sample of approximately 6,000 was selected from the population of approximately 60,000 American Catholic priests and asked to complete a detailed sociological questionnaire. A subsample was selected for psychological evaluation. This consisted of an in-depth interview by a Ph.D. psychologist and the subjects: self-descriptions on four instruments: Personal Orientation Inventory (Shostrom, 1963). The Loyola Sentence Completion Blank for Clergymen (Sheehan, 1971), Self-Anchoring Rating Scale of Maturity of Faith (Adapted from Strunk, 1967). and Identity Scale (Henry and Sims, 1968).

Psychological evaluation data have been collected on 218 American Catholic priests who are the subjects of this thesis. 
of these subjects, $141(65 \%)$ are diocesan priests and 77 (35\%) are religious priests.

The number of priests in the various age categories is shown in Table 1 .

TABLE 1

NUMBER OF PRIESTS ACCORDING TO AGE

AGE

NUMBER OF PRIESTS

\% OF PRIESTS

\begin{tabular}{lccc}
\hline $26-35$ & 58 & $\cdot$ & $26.6 \%$ \\
\hline $36-45$ & 67 & $30.8 \%$ \\
\hline $46-55$ & 50 & $22.9 \%$ \\
\hline $56+$ & 43 & $19.7 \%$ \\
\hline TOTAL & 218 & $100.0 \%$ \\
\hline
\end{tabular}


Table 2 illustrates that the sample consisted of priests who have been ordained 0 to 10 years, 11 to 20 years, 21 to 30 years, and 30 or more years.

TABLE 2

NUMBER OF PRIESTS ACCORDING TO YEARS ORDAINED

YEARS ORDAINED NUMBER OF PRIESTS

$\%$ OF PRIESTS

\begin{tabular}{ccc}
\hline $0-10$ & 27 & $35.3 \%$ \\
\hline $11-20$ & 65 & $29.8 \%$ \\
\hline $21-30$ & 46 & $21.1 \%$ \\
\hline $31+$ & 30 & $13.8 \%$ \\
\hline TOTAL & 218 & $100.0 \%$ \\
\hline
\end{tabular}


Description of the Ioyola Sentence

Completion Blank for Clergymen (ISCBC)

The Loyola Sentence Completion Blank for Clergymen is a projective technique which consists of 72 items. The test measures adjustment in six areas, Self, Interpersonal Relations, Psychosexual Maturity, Church-Faith-Religion, Priesthood, and Job Satisfaction. It also provides a total adjustment score. The subjects were asked to complete such "incomplete sentences" ası

My greatest worry is

I became a priest because

Celibacy

My present assignment

Each sentence completion was scored according to a sevenpoint rating scale of adjustment. A numerical score of 1,2 , or 3 was given to responses which were extremely positive, quite positive, or mildly positive respectively. ("A positive response is one that expresses an attitude of optimism, happiness, hope, humor, or a positive feeling toward other people [Sheehan, 1971, p. 65].") A score of 4 was given for responses which were judged to be neutral (neither positive or negative). A numerical value of 5,6 , or 7 was given for negative or conflictual completions which were somewhat mild, somewhat severe, or very severe respectively. (Negative responses "include depression, hostile reactions, statements of y̧nhappy experiences, expectations of failure, interpersonal difficulties, sexual problems, and statements of past conflicts [Sheehan, 1971, p. 65].") 
The scoring of the completions was objective in so far as examples in the test manual provided the main criterion for assigning specific scores. The completions were scored by four graduate students in clinical psychology at Loyola University of Chicago.

Procedure

Pearson product-moment correlations were computed between the 12 POI scales and the seven scores on the ISCBC (an overall score and six subtest scores). In addition, intercorrelations among the scales of the POI as well as the intercorrelations among the subtests and total score of the ISCBC were computed. 


\section{CHAPTER IV}

RESULTS AND DISCUSSION

TABLE 3

CORRELATION OF POI SCALES AGAINST ISCBC SUBTESTS AND TOTAL

ISCBC SUBTESTS AND TOTAL SCORE

POI Self Inter. Psych. Church- Priest- Job Total Scales Relat. Matur. Faith-Rel. hood Satis.

\begin{tabular}{|c|c|c|c|c|c|c|c|}
\hline TC & $-.24 * *$ & $-.39 * *$ & $-.32 * *$ & $-.24 * *$ & $-.17^{*}$ & $-.28 * *$ & $-.31 * *$ \\
\hline$I$ & $-.26 * *$ & $-.34 * *$ & $-.44 * *$ & -.03 & -.03 & -.12 & $-.22 * *$ \\
\hline SAV & -.13 & $-.33 * *$ & $-.39 * *$ & -.11 & -.12 & $-.21 * *$ & $-.15^{*}$ \\
\hline Ex & $-.19 * *$ & $-.24 * *$ & $-.33^{* *}$ & .05 & .01 & $=.01$ & $-.15^{*}$ \\
\hline Fr & $-.18 * *$ & $-.22^{* *}$ & $-.33^{* *}$ & .00 & .10 & -.01 & -.10 \\
\hline $\mathbf{S}$ & $-.23 * *$ & $3 * *$ & $3 * *$ & -.07 & -.07 &.- .11 & $-.23 * *$ \\
\hline$S r$ & $-.35^{* *}$ & $-.38 * *$ & $-.37^{* *}$ & $-.18 * *$ & $-.22 * *$ & $-.34 * *$ & $-.36 * *$ \\
\hline Sa & $-.23 * *$ & $-.19 * *$ & $-.30 * *$ & .02 & -.02 & -.12 & $-.18 * *$ \\
\hline NC &. .13 & $-.27^{* *}$ & $-.33^{* *}$ & .02 & -.01 & .03 & -.08 \\
\hline Sy &. .11 & $-.29 * *$ & $-.26 * *$ & -.08 & -.13 & -.11 & -.13 \\
\hline A & $-.16 *$ & $-.23 * *$ & $-.31 * *$ & -.12 & -.07 & -.09 & $-.16 *$ \\
\hline C & $-.20 * *$ & $-.23^{* *}$ & $-.30^{* *}$ & -.03 & -.01 & -.09 & $-.19^{* *}$ \\
\hline & - & & & & \multicolumn{3}{|c|}{$\begin{array}{r}\text { * Significant at .01 } \\
\text { level } \\
\text { * Significant at .05 } \\
\text { level }\end{array}$} \\
\hline
\end{tabular}


Pearson product-moment correlations of the POI scales against the ISCBC subtests and total score are shown above. Since the lower the score on the ISCBC the better is a subject's adjustment, and since the higher the score on the POI the more self-actualized the person is, the above negative correlations are, therefore, indicative of positive relationships, in addition, positive correlations shown above are indicative of negative relationships.

Examination of Table 3 indicates that the intercorrelations between the Personal Orientation Inventory and the Loyola Sentence Completion Blank for Clergymen are in the low and moderate ranges; there are no high correlations between the two instruments. This indicates that the POI scales are measuring areas which are somewhat different than those which the Loyola Sentence Completion Blank for Clergymen is measuring. The highest correlation between the two tests is .44 . which accounts only for an estimated 19 per cent of the variance. The fact that only moderate and low correlations were found between the two instruments is not surprising since they were designed for such different purposes. The correlation matrix between the POI and the ISCBC lends support to Maslow's notion that adjustment is not necessaril. equivalent to psychological health or self-actualization.

The total column of the Loyola Sentence Completion Blank for clergymen indicates that there is a positive significant relationship between total adjustment and nine of the POI scales. Time Competence (TC). Inner-Directedness (I), Spontaneity (S). 
Self-Regard $(\mathrm{Sr})$, Self-Acceptance $(\mathrm{Sa})$, and Capacity for Intimate Contact $(C)$ are positively related to total adjustment on the Loyola Sentence Completion Blank for Clergymen at the .01 level of significance. Self-Actualizing Value (SAV), Existentiality (Ex), and Acceptance of Aggression (A) are positively related to the overall adjustment score on the ISCBC at the .05 level of significance. No significant relationships were found among Feeling Reactivity (Fr), Nature of $\operatorname{Man}(\mathrm{Nc})$, and Synergy (Sy). The mean $r$ of .20 between the POI scales and total adjustment on the ISCBC indicates that there is a low positive significant (at the .01 level) relationship between self-actualization and relative adjustment among American Catholic priests.

The POI scales which correlate the highest with total adjust ment on the Loyola Sentence Completion Blank. for Clergymen are Self-Regard (.36) and Time Competence (.31). These two scales are positively related to all the ISCBC subtests (not only to Self, Interpersonal Relations, and Psychosexual Maturity, but also to Church, Priesthood, and Job Satisfaction). In other words, overall adjustment is significantly related to "the ability to like one's self because of one's strength as a person ( $\mathrm{Sr}$ ) (Shostrom, 1968, p. 20)," and to the ability to live more fully in the present (TC). In addition, total adjustment is positively related at the .01 level of significance to being autonomous (I) $(.22)$, and to being free to express oneself spontaneously (S) (.23). Significant relationships at the .01 level were also found between total adjustment and the ability to develop mean- 
ingful interpersonal relationships (c) (.19), and the ability to accept one's self even though one has weaknesses (Sa) (218). In addition, positive significant relationships at the .05 level were found between total adjustment and the ability to be flexible in applying principles to life (Ex) (.15), having the same values as people judged to be self-actualized (SAV) (.15), and the ability to accept feelings of anger or aggression (A) (.16). Furthermore, an analysis of the correlation matrix between the two instruments reveals two patterns. First, three subtests of the Loyola Sentence Completion Blank for Clergymen--Self, Interpersonal Relations, and Psychosexual Maturity--are positively related to the POI scales. These subtests of the ISCBC are the ones which are measuring variables which have been of concern and interest in past psychological research. Nine of the POI scales are significantly related to the Self subtest ( 8 at the .01 level; 1 at the .05 level). All of the POI scales are related at the .01 level of significance to Interpersonal Relations and to Psychosexual Maturity. The latter subtest has the highest correlations of all the ISCBC subtests with the POI scales, ranging from . 44 to .26. Therefore, the POI and the ISCBC both tap the areas of Self. Interpersonal Relations, and Psychosexual Maturity. This indicates that self-actualization among American Catholic priests is related to a positive selfconcept, satisfying interpersonal relations, and psychosexual maturity. Secondly, only a relatively small number (seven) of positive significant correlations were found among the Church. 
Priesthood, and Job Satisfaction subtests of the Loyola Sentence Completion Blank for Clergymen and the POI scales. Thus, the Personal orientation Inventory is not tapping attitudes and feelings in the areas of Church, Priesthood, and Job Satisfaction. 


\section{TABLE 4}

\section{SUBSCAIE INTERCORRELATIONS FOR THE POI}

POI Scales I SAV Ex Fr $S$ Sr Sa NC Sy A $C$

Tc

.55

$.38 \quad .51$

$.33 .46 \quad .49$

.52 .24

.29

$.38 \quad .45$

I .66

.77

.76

$.80 \quad .66 \quad .80$

.53

.41

$.77 \quad .85$

SAV

$$
.47
$$

.52

.63 .57

.37

.43

.61

.51 .52

Ex

$\begin{array}{llllllll}.44 & .54 & .40 & .58 & .38 & .42 & .47 & .67\end{array}$

Fr

.66

.42

.51

.33

.22

$.75 \quad .73$

$\mathrm{S}$

.51

$\begin{array}{lllll}.56 & .40 & .35 & .65 & .68\end{array}$

Sr

$\begin{array}{lllll}.50 & .43 & .27 & .48 & .51\end{array}$

$\mathrm{Sa}$

$\begin{array}{llll}.28 & .22 \quad .64 & .64\end{array}$

Nc

$.43 \quad .26 \quad .32$

Sy

.31 .31

A

C

The above matrix shows many moderate and high correlations among the subscales which suggest that some of the subscales do not contribute to the POI in a unique way; in other words, they lack unique variance. The highest correlations are found between Inner-Direction and the other subscales which is not unexpected since 123 of the 150 items are scored for Inner-Direction. These findings are consistent with the results reported by klavetter and Mogar (1967). Item analysis is suggested to exclude those subscales which do not make a unique contribution to the POI. 
TABLE 5

INTERCORRELATIONS FOR ISCBC SUBTESTS AND TOTAL SCORE

Interpers. Psych. Church-Faith-Priest- Job Total

Relations Matur. Religion hood Satis.

Self

.32

.37

.22

.22

.40

.82

Interpers.

.53

.41

.40

.47

.52

Relations

.27

.22

.29

.49

Maturity.

Church-Faith-

Religion

.51

.56

.52

Priesthood

.53

.54

Job Satis-

.65

faction

Examination of the above matrix reveals moderate correlations of the subtests with the total score, with the exception of the Self subtest which correlates .82 with the total score of adjustment. Low and moderate correlations are found among the subtests. Thus, the LSCBC fairly well approaches Thorndike's (1949) criteria for a combination of tests--low intercorrelations among the subtests and moderate relationships between the subtests and the total score. These criteria indicate that each subtest makes a unique contribution to the test, and no one subtest's relationship with the total score is so great that it could be a substitute for the whole test. 


\section{SUMMARY AND CONCLUSIONS}

The purpose of the present study was to investigate the relationship between self-actualization and relative adjustment among American Catholic priests. The Personal Orientation Inventory (POI) (Shostrom, 1963), a measure of self-actualization, and the Ioyola Sentence Completion Blank for Clergymen (ISCBC) (Sheehan, 1971), a measure of relative adjustment, were administered to 218 American Catholic priests $(65 \%$ diocesan; $35 \%$ religious). These subjects were participants of a larger study entitled The Loyola Psychological Study of the Ministry and Iife of the American Priest (Kennedy and Heckler, 1971).

The results of the study are as follows, .

1) Among a sample of American priests there is a low positive correlation between self-actualization, as measured by the Personal Orientation Inventory, and relative adjustment, as measured by the Loyola Sentence Completion Blank for Clergymen (mean $r$ of .20 , significant at the .01 level, between POI scales and LSCBC total score).

2) The POI scales which correlate the highest with relative total adjustment are Self-Regard (.36) and Time Competence (.31). Thus, of all the various aspects of selfactualization measured by the POI, liking one's self because of one's worth or strength as a person and the ability to live in the present are the most important for overall adjustment among American priests. 
3) The Personal Orientation Inventory and the Loyola Sentence Completion Blank for Clergymen measure areas which are somewhat different. Both tap attitudes and feelings regarding Self, Interpersonal Relations, and Psychosexual Maturity. Thus, self-actualization among American priests is positively related to a positive self-concept, good interpersonal relations, and psychosexual maturity. On the other hand, the POI does not tap attitudes and feelings in the areas of Church-Faith-Religion. Priesthood, and Job Satisfaction.

4) The subscale intercorrelations for the POI indicate that some of the subscales do not contribute to the POI in a unique way; in other words, they lack unique variance. Item analysis is recommended to exclude those subscales which do not make a unique contribution to the POI. The intercorrelations among the subtests and the total score of the ISCBC suggest that each subtest makes a unique contribution to the test, and that no subtest's relationship with the total score is so great that it could be a substitute for the whole test. 


\section{REFERENCES}

Braun, J. R. Effects of "typical neurotic" and "after therapy" sets on Personal Orientation Inventory scores. Psychological Reports, 1966, 19,1282.

Braun, J. R. Search for correlates of self-actualization. Perceptual and Motor Skills, 1969, 28, 557-558.

Braun, J.R. \& Asta, P. A comparison of "real" versus "ideal" self with a self-actualization inventory. The Journal of Psychology, 1969, 72, 159-164.

Braun, J.R. \& Ia Faro, D. A further study of the fakability of the Personal Orientation Inventory. Journal of Clinical Psychology, 1969, 25, 296-299.

Buhler, C. Values in psychotherapy. New York: Free Press of Glencoe, 1962 .

Burwen, I. S., Campbell, D. T.. \& Kidd, J. The use of a sentence completion test in measuring attitudes toward superiors and subordinates. Journal of Apolied Psychology, 1956, 40, 248-250.

Damm, V. J. Overall measures of self-actualization derived from the Personal Orientation Inventory. Educational and Psychological Measurement. 1969, 29, 977-981.

Ebner, E. \& Shaw, F.J. An investigation of modes of response to contradictions. Psychological Reports, 1960, 6, 206.

Ellis, A. Reason and emotion in psychotherapy. New York, Lyle Stuart, 1962 .

Fisher, G. Performance of psychopathic felons on a measure of self-actualization. Educational and Psychological Measurement, $1968,28,561-563$.

Fisher, G. \& Silverstein, A. B. Simulation of poor adjustment on a measure of self-actualization. Journal of clinical Psychology, 1969, 25, 198-199.

Fox, J., Knapp, R. R. \& Michael, W. B. Assessment of selfactualization of psychiatric patients: Validity of the Personal Orientation Inventory. Educational and Psychological Measurement, 1968, 28, 565-569.

Fromm, E. Escape from freedom. New York: Rinehart, 1941. Fromm, E. The art of loving. New York, Harper, 1956. 
Goldberg, P. A. A review of sentence completion methods in personality assessment. Journal of Projective Techriques and Personality Assessment, $1965, \frac{1}{29}, 12-45$.

Goldberg, P. A. The current status of sentence completion methods. Journal of Projective Techniques and Personality Assessment, 1968, $32, \frac{1}{215-221 .}$

Gorman, J. \& Kobler, F. J. Loyola Seminarian Sentence Completion Test. Loyola University (Chicago), 1963. Copyright 1967.

Graff, R. W., Bradshaw, H. E., Danish, S. J., Austin, B. A. \& Altekruse, $M$. The POI: A validity check. Educational and Psychological Measurement, 1970, 30, 429-432.

Grossack, M. M., Armstrong, T. \& Lussiev, G. Correlates of selfactualization. Journal of Humanistic Psychology, 1966,6 , 87-88.

Harlow, R. G. Masculine inadequacy and compensatory development of physique. Journal of Personality, 1951, 19, 312-323.

Henry, W. E., Sims, J. \& Spray, S. Mental health professionals in Chicago: Some preliminary observations on origins and practice. Research in Psychotherapy, 1968, 3, 547-572.

Horney, K. The neurotic personality of our time. New York: Norton, 1937.

Homey, K. Our inner conflicts. New York: Norton, 1945.

Horney, K. Neurosis and human growth. New York: Norton, 1950.

II ardi, R. I. \& May, W. T. A reliability study of Shostrom's Personal Orientation Inventory. Journal of Humanistic Psychology, 1968, 8, 68-72.

Kennedy, E. C. \& Heckler, V. J. The Loyola psychological study of the ministry and life of the American priest. National Conference of Catholic Bishops. 1971.

Klavetter, R. E. \& Mogar, R. E. Stability and internal consistency of a measure of self-actualization. Psychological Reports, 1967, 21, 422-424.

Knapp, R. R. Relationship of a measure of self-actualization to neuroticism and extraversion. Journal of Consulting Psychology, 1965, 29, 168-172.

Ie May, M. I. \& Damm, V. J. Relationship of the Personal Orientation Inventory to the Edwards Personal Preference Schedule. Psychological Reports, 1969, 24, 834. 
Maslow, A. Motivation and personality. New York: Harper, 1954

Maslow, A. Toward a psychology of being. New York, Van Nostrand, 1962 .

Maslow, A. Toward a psychology of being. (2nd edition) New Yorks Basic Books, 1968.

May, R., Angel, T., \& Ellenberger, H. Existence. New York Basic Books, 1958 .

Menges, R. J. \& Dittes, J. E. Psychological studies of clergymen. New York: Thomas Nelson and Sons, 1965.

Murstein, B. (ed.) Handbook of projective techniques. New Yorks Basic Books, 1965 .

Perls, F. S., Hefferline, R., \& Goodman, P. Gestalt therapy. New York: Julian, 1951.

Perls, F. S. Ego, hunger and aggression. New York House, 1969 .

Reisman, D., Glazer, N., \& Denney, R. The lonely crowd. New York: Doubleday, 1950.

Rogers, C. Client-centered therapy. Boston: Houghton Mifflin, 1951.

Rogers, $C$. On becoming a person. Boston: Houghton Mifflin, 1961.

Rokeach, M. The open and closed mind. New York, Basic Books, 1960.

Schultz, K. V. The psychologically healthy person: a study in identification and prediction. Journal of Clinical Psychol:ogy, 1958, 14, 112-117.

Sheehan, M. The Loyola Sentence Completion Blank for Clergymen: Construction and validation. Unpublished master's thesis. Loyola University of Chicago. 1971.

Sheridan, E. The Loyola Seminarian Sentence Completion Tests A validation study. Unpublished doctoral dissertation. Loyola University of Chicago, 1968.

Shostrom, E. L. Personal Orientation Inventory. San Diego, Calif.: Educational and Industrial Testing Service, 1963. 
Shostrom, E. I. An inventory for the measurement of selfactualization. Educational and Psychological Measurement, $1964,24,207-218$.

Shostrom, E. I. EITS manual for the Personal Orientation Inventory. San Diego, Calif.: Educational and Industrial Testing Service, 1968.

Shostrom, E. I. \& Knapp, R. R. The relationship of a measure of self-actualization (POI) to a measure of pathology (MMPI) and to therapeutic growth. American Joumal of Psychotheraoy, 1966, 20, 193-202.

Stewart, R. A. C. \& Webster, A. C. Scale for theological conservatism, and its personality correlates. Perceptual and Motor Skills, 1970, 30, 867-870.

Strunk, 0. Self-anchoring scaling for study of perceptions of religious maturity. Perceptual and Motor Skills, 1967, 25, $471-472$.

Thorndike, R. I. Personnel selection: Tests and measurement techniques. New York: John Wiley and Sons. 1949.

Walter, V. A. \& Jones, A. W. An incomplete sentence test and the attitudes of manual arts therapy patients. Journal of Counseling Psychology, 1956, 3, 140-144.

Webster, A. C. Patterns and relations of dogmatism, mental health and psychological health in selected religious groups Unpublished doctoral dissertation. Syracuse University, 1966.

Webster, A. C. \& Stewart, R. A. C. Psychological attitudes and beliefs of ministers. Anvil Quarterly, 1969, 1, 11-16.

Zaccaria, J.S. \& Weir, W. R. A comparison of alcoholics and selected samples of non-alcoholics in terms of a positive concept of mental health. Journal of Social Psychology, $1967.71,151-157$. 
Approva 1 Sheot

The thesis submitted by Thomas Murphy has been read and approved by members of the Department of Psychology.

The final copies have been exarined by the Director of the thesis and the signiture which appears below verifies the fact that all necessary changes have been incorporated and that the thesis is now given final approval with regard to content, form, and mechanical accuracy.

The thesis is, therefor, accepted in partial fulfillment of the requirement for the degree of laster of Arts.

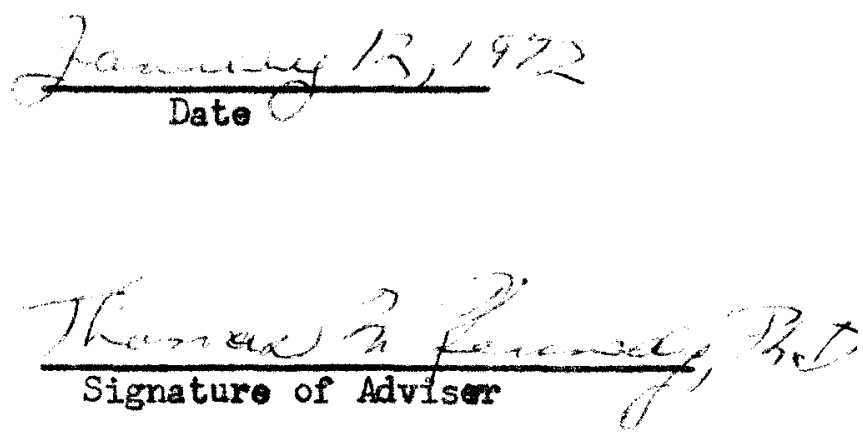

